\title{
Monetary Policy Response in the Republic of North Macedonia and the Republic of Albania for Coping with the Pandemic COVID-19 in 2020
}

\author{
Alba Pollozhani \\ South East European University, North Macedonia \\ Shenaj Hadzimustafa \\ South East European University, North Macedonia
}

\section{Abstract}

This study aims to analyse how the monetary policies of the Republic of North Macedonia and the Republic of Albania, as one of the two critical macroeconomic policies, have reacted in response to COVID-19 for the year 2020. Last year, the year 2020, the pandemic caused these two countries to react through monetary policy. This research examines how central banks of both countries have changed traditional monetary policy tools for tackling the pandemic, starting with open market operations, required reserve ratio, the overnight loans interest rate, and the available deposits interest rate. The research continues with analyzing whether they were used and what non-traditional tools were applied in that period. The study analysis concludes which monetary policies have been pursued in the Republic of North Macedonia and the Republic of Albania, whether there have been nontraditional tools and how the scope for interbank interest rate volatility has changed. Our study revealed that both countries had pursued an expansive monetary policy, there were also non-traditional tools, and the scope for interbank interest rate volatility has shifted towards narrowing.

Keywords: monetary policy, central bank, traditional tools, non-traditional tools, interbank interest rate

JEL classification: E49, E58, E59

Paper type: Research article

Received: Jun 24, 2021

Accepted: July 8, 2021

DOI: $10.54820 /$ SBYM9385 


\section{Introduction}

In the first quarter of 2020, the COVID-19 pandemic unexpectedly hit the entire world economy. Major central banks (CBs), on their own, responded to the crisis with a new round of monetary relaxation. Central banks continue their expansionary monetary policies by extending the period of unconventional policy measures. This paper aims to present the anti-crisis monetary policy measures the central banks took in the Republic of North Macedonia and the Republic of Albania.

The structure of the paper is subordinated to its declared analytical purpose. The paper gives an overview of the literature in this area, the methodology used in the paper, continues with the case study analyses of the monetary policies in the two countries and ends with the conclusions and the recommendations.

The topic of this paper is related to the analysis of the monetary policy for 2020 of two neighboring Balkan countries such as The Republic of Northern Macedonia and the Republic of Albania.

The main questions answered in the paper are: How have traditional tools changed in these two countries?; Did the Central banks in the two countries apply non-traditional tools, and if so, what kind?; and as a conclusion: Has an expansive or restrictive monetary policy been pursued to cope with the pandemic situation in the two analyzed countries?

The data sources used were from the National Bank of North Macedonia and Bank of Albania databases and reports.

\section{Literature Review}

The Monetary policy or the demand side of the economic policy refers to the actions taken by a nation's central bank to control the money supply and achieve macroeconomic goals that promote sustainable economic growth. So, it is one of the two critical macroeconomic policies (Kenton, 2021).

Monetary policy is one of the two principal tools (the other being fiscal policy) by which government authorities in a market economy regularly influence the pace and direction of overall economic activity, notably including not only the level of aggregate output and employment but also the general rate at which prices rise or fall. The evidence from experience, in one country after another, makes clear that the exercise of this control - monetary policy - powerfully influences the economy of a country, for either good or ill (Friedman, 2015).

A central bank is a financial institution given privileged control over the production and distribution of money and credit for a nation or a group of nations. In modern economies, the central bank is usually responsible for formulating monetary policy and regulating member banks (Bank of Albania, 2020a).

Central banks have four main monetary policy tools: the reserve requirement, open market operations, the discount rate, and interest on reserves. Most central banks also have a lot more tools at their disposal. These tools can either help expand or contract economic growth (Amadeo, 2021).

In regular times the central bank is neither involved in direct lending to the private sector or the government nor in outright purchases of government bonds, corporate debt, or other types of debt instruments. But in, so to speak, abnormal times, conventional monetary policy tools may prove insufficient to achieve the central bank's objective (Smaghi, 2009).

During the global financial crisis, central banks implemented non-standard measures to pull their economies out of financial distress (Kenton, 2021). In addition to traditional tools during the crisis, non-traditional monetary policy tools have been 
used to cope even better with the consequences during and after the crisis. Nonstandard monetary policies include quantitative easing, forward guidance, collateral adjustments, and negative interest rates.

The Central Bank of the Republic of Northern Macedonia was established and had been operating since 1946 and is $100 \%$ state-owned. Under the legally defined functions, the central bank designs and implements the country's monetary policy. The primary purpose of monetary policy is to maintain price stability, during which it is independent in the performance of its functions. To achieve the main goal, it indirectly influences the management of the traditional tools of this policy, such as open market operations, required reserve ratio, overnight deposits and in seven days deposits, and overnight loans. In addition, the National Bank supports the country's economic policy and financial stability by not compromising the realization of the main goal, respecting the principles of the market economy.

The Central Bank of the Republic of Albania was established and has been functioning since 1925, and this bank has $100 \%$ state ownership. The central bank, under the legally defined functions, designs and implements the country's monetary policy. The primary purpose of monetary policy is to maintain price stability. It indirectly achieves this goal by managing traditional policy tools such as open market operations, required reserve ratio overnight deposits, overnight loans, liquidity management, and monetary policy implementation (Bank of Albania, 2021).

According to Loayza et al. (2021), COVID-19 not only represents a worldwide public health emergency but has become an international economic crisis that could surpass the global financial crisis of 2008-09. Containment and mitigation measures are necessary to limit the spread of the virus and save lives. However, they come at a cost, as shutdowns imply reducing the economy. Policymakers will need to carefully weigh the effectiveness and socioeconomic consequences of containment and mitigation policies, responding to epidemiological evidence on how the virus spreads and trying to avoid unintended consequences.

In the Western Balkans Regular Economic Report: Spring 2021, published by the World Bank (2021), the economic impact reported by firms surveyed has been substantial. In both countries, the Republic of North Macedonia and the Republic of Albania, at least 50 percent of firms in the most affected sectors had been forced to close to some extent, while those that remained open saw activity plunge. Surveys conducted at the onset of the crisis show that the total reported layoffs are significant. Access to raw materials and imports has been less constrained than liquidity, declining demand, and uncertainty.

The Bank of Albania undertook immediate measures to support the Albanian economy, hit by the coronavirus pandemic in response to the pandemic. According to The National Bank of North Macedonia's annual reports (NBRM, 2020a), the NBRM released its monetary policy during 2020 to mitigate the negative consequences of the covid-19 pandemic. This strategy is in cooperation and harmony with the fiscal policy of the country. In this regard, the measures undertaken by the Bank of Albania, within its field of competence, enable and complete the fiscal package announced by the Albanian Government, which aims at shifting a part of the financial bill to counter the crisis from private to the public sector (Bank of Albania, 2020b).

\section{Methodology}

The analysis in the paper was based on the official data published on the official websites of the two countries' central banks, which provide the necessary information needed to identify the changes in the monetary policy seen through 
traditional and non-traditional tools of both countries. When analyzing the traditional assets, monthly quantitative data on the interest rates of traditional monetary policy tools, such as open market operations, required reserve ratio, available reserves, overnight and overnight loans, were obtained for the Republic of North Macedonia. Whereas open market operations, required reserve ratio, available reserves and liquidity management, and implementation of monetary policy were analyzed for Albania. The analysis is focused on the year 2020. The data was used to perform dynamic analysis to see volatility both at baseline and relative magnitude.

The data is being used to assess how the monetary policies in the Republic of North Macedonia and Albania changed to cope with the pandemic situation and to see if any non-traditional tool is being used for this purpose.

\section{Case studies analysis}

\section{Republic of North Macedonia}

The monetary authority in the Republic of Northern Macedonia is the National Bank of the Republic of North Macedonia (NBRM), located in the capital city, Skopje.

During the pandemic, different monetary authorities worldwide have used traditional and non-traditional tools to smoothen the adverse effects that the pandemic situation has caused in the economies. The set of tools that NBRM used in 2020 were as follows: traditional tools such as open market operations, required reserve ratio, and overnight loans; and non-traditional tools such as reactivation of the nonstandard reserve demand measure, expansion of the portfolio of eligible securities, tariff reduction, and extension of the deadlines for loans and the bank's liquidity assessment report, are used by the central bank of this country to change his monetary policy.

The traditional tools used by the NBRM' reports (2020a-d) of the Republic of North Macedonia were changed by the central bank as follows:

- Open market operations - the interest rates of treasury bills were decreased by 25 basis points from $2.00 \%$ to $1.75 \%$ in April, and they were in May with 25 basis points from $1.75 \%$ to $1.50 \%$ and thus remained until the end of 2020.

- Required reserves - For banks, the required reserve ratios remained unchanged during 2020: $8.00 \%$ of domestic foreign exchange reserves, $50.00 \%$ of domestic foreign exchange reserves with foreign exchange clause, and $15.00 \%$ of foreign currency reserves. For savings houses, the required reserve ratios remained unchanged during 2020 at the level of $2.50 \%$ of their reserves.

- Available deposits - the available overnight reserves interest rate remained unchanged at a $0.15 \%$ rate during 2020 . For seven-day available reserves, the interest rate also remained unchanged for 2020 at a $0.30 \%$ rate.

- One-day loans - the interbank interest rate was decreased by 25 basis points from $2.50 \%$ to $2.25 \%$ in April and decreased again by 25 basis points from $2.25 \%$ to $2.00 \%$ in May and thus remained unchanged until the end of 2020.

All changes in the traditional tools of the country's monetary policy during 2020 are presented in Table 1, while the required reserves ratio is presented in Table 2. 
Table 1

Interest rates of traditional monetary policy tools in the Republic of North Macedonia in 2020

\begin{tabular}{lcccc}
\hline Month & $\begin{array}{c}\text { Overnight } \\
\text { Deposits }\end{array}$ & $\begin{array}{c}\text { Seven days } \\
\text { Deposits }\end{array}$ & Treasury Bills & $\begin{array}{c}\text { Overnight } \\
\text { Loans }\end{array}$ \\
\hline January & $0.15 \%$ & $0.30 \%$ & $2.00 \%$ & $2.50 \%$ \\
\hline February & $0.15 \%$ & $0.30 \%$ & $2.00 \%$ & $2.50 \%$ \\
\hline March & $0.15 \%$ & $0.30 \%$ & $2.00 \%$ & $2.50 \%$ \\
\hline April & $0.15 \%$ & $0.30 \%$ & $1.75 \%$ & $2.25 \%$ \\
May & $0.15 \%$ & $0.30 \%$ & $1.50 \%$ & $2.00 \%$ \\
June & $0.15 \%$ & $0.30 \%$ & $1.50 \%$ & $2.00 \%$ \\
July & $0.15 \%$ & $0.30 \%$ & $1.50 \%$ & $2.00 \%$ \\
August & $0.15 \%$ & $0.30 \%$ & $1.50 \%$ & $2.00 \%$ \\
September & $0.15 \%$ & $0.30 \%$ & $1.50 \%$ & $2.00 \%$ \\
\hline October & $0.15 \%$ & $0.30 \%$ & $1.50 \%$ & $2.00 \%$ \\
November & $0.15 \%$ & $0.30 \%$ & $1.50 \%$ & $2.00 \%$ \\
December & $\mathbf{0 . 1 5 \%}$ & $\mathbf{0 . 3 0 \%}$ & $1.50 \%$ & $2.00 \%$ \\
\hline
\end{tabular}

Source: Authors' calculations

Table 2

Banks' reserves requirement ratios in the Republic of North Macedonia in 2020

\begin{tabular}{ccccc}
\hline Year & $\begin{array}{c}\text { Banks' reserve } \\
\text { requirement } \\
\text { ratios - in } \\
\text { domestic } \\
\text { currency }\end{array}$ & $\begin{array}{c}\text { Banks' reserve } \\
\text { requirement ratios - } \\
\text { in domestic } \\
\text { currency with FX } \\
\text { clause }\end{array}$ & $\begin{array}{c}\text { Banks' reserve } \\
\text { requirement } \\
\text { ratios - in } \\
\text { foreign } \\
\text { currency }\end{array}$ & $\begin{array}{c}\text { Reserve } \\
\text { requirement } \\
\text { ratio of } \\
\text { savings } \\
\text { houses }\end{array}$ \\
\hline 2020 & $8.00 \%$ & $50.00 \%$ & $15.00 \%$ & $2.50 \%$ \\
\hline
\end{tabular}

Source: Authors' calculations

Non-traditional tools of the Republic of North Macedonia were changed by the central bank as follows:

- Reactivation of the non-standard reserve demand measure. The base of requirement reserve was reduced to provide targeted support for easing credit conditions.

- Expansion of the porffolio of eligible securities. This decision was made to ensure the liquidity of domestic banks by the National Bank, including the longest-lived domestic government bonds and Eurobonds issued by the state in international financial markets.

- Tariff reduction. A decision was made to abolish fees charged so far for withdrawing and returning cash to the central vault of the National Bank. The council also approved a decision to remove the fee for providing data to individuals from the National Bank Credit Registry for their debt to banks and savings houses. Furthermore, a decision was made for all citizens needing to take the certificate from Credit Registry for free (NBRM, 2020d).

- Extension of the deadlines for loans and the bank's internal Liquidity Assessment Report. This extension of the deadline for loans was prepared for enterprises and households that may face difficulties during this period due to the Covid 19 pandemic. The decision for this extension was made twice during 2020. Also, it was decided to extend the deadline for banks to submit their first internal Liquidity Assessment Report (NBRM, 2020d).

The space of interbank interest rate volatility was changed toward narrowing by 50 basis points. This is because the interest rate of overnight loans decreased by 100 basis points from $2.50 \%$ to $2.25 \%$ in March and $2.00 \%$ in April and thus remained until 
the end of 2020. In parallel with the narrowing of the space for volatility, the interbank interest rate itself decreased by 50 basis points during 2020 from $2.00 \%$ to $1.75 \%$ in April and again from $1.75 \%$ to $1.50 \%$ in May and thus remained until the end of 2020. Changes in both the interbank interest rate and the volatility space of the interbank interest rate are shown by a graph in Figure 1.

Figure 1

Interest Rates of Traditional Monetary Policy Tools (except Required Reserve) in the Republic of North Macedonia in 2020



Source: Authors' calculations

The dynamic analysis is presented by a graph in Figure 2 and shows that the interbank interest rate decreased relatively slightly more than the overnight loan interest rate. In April, the interbank interest rate decreased by $13 \%$ and the overnight loan interest rate by $10 \%$. In May, the interbank interest rate was decreased again by $14 \%$, and the overnight loans interest rate by $11 \%$.

Figure 2

Dynamic Analysis of Interest Rates of Traditional Monetary Policy Tools in the Republic of North Macedonia in 2020.

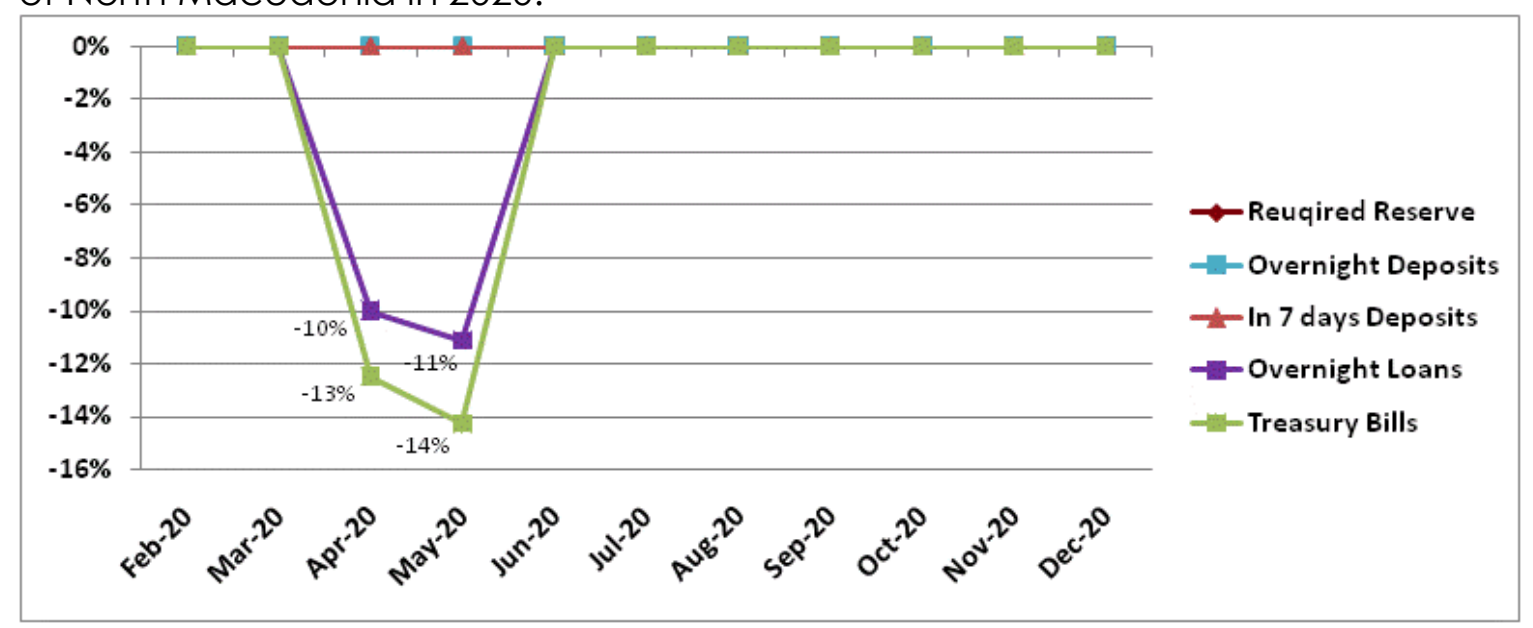

Source: Authors' calculations

Based on the changes made to the traditional and non-traditional tools, the conditions are met to conclude that an expansionary monetary policy was pursued in the Republic of North Macedonia during the pandemic period for 2020. 


\section{The Republic of Albania}

The Republic of Albania is a Balkan country with the capital city Tirana. The Bank of Albania is the central bank of Albania. During 2020, the traditional tools such as open market operations, required reserve ratio, overnight deposits, overnight loans, and liquidity management and implementation of monetary policy, and non-traditional tools such as debt payment deadlines, suspension of dividend distribution, and lower banking sector electronic systems infrastructure costs, were used by the central bank of this country as an answer to the new situation that stroke the whole world.

According to the Bank of Albania reports (2020b-d), the traditional tools of the Republic of Albania that were used changed as follows:

- Open market operations - the interest rates of treasury bills were decreased by 50 basis points from $1.00 \%$ to $0.50 \%$ in April and thus remained until the end of 2020

- Required reserve - The required reserve ratios remained unchanged during 2020 as follows: the reserve ratio in lek was $7.50 \%$ for the liabilities included in the reserve base to which a 0 (zero) reserve ratio is not applied and with a maturity term up to 12 months; and $5.00 \%$ for the liabilities included in the reserve base to which a 0 (zero) reserve ratio is not applied with an initial maturity term of over 12 months to 2 years. The reserve ratio for foreign currency was $12.50 \%$ for the liabilities included in the reserve base to which a 0 (zero) reserve rate is not applied when the ratio of "liabilities in the relevant currency included in the reserve base to which a 0 (zero) reserve ratio is not applied/ the total of liabilities included in the reserve base to which a 0 (zero) reserve ratio is not applied to" of the bank is up to 50 (fifty) percent" and $20 \%$ for the liabilities included in the reserve base to which a 0 (zero) reserve rate is not applied, when the ratio of "liabilities in the relevant currency included in the reserve base to which a 0 (zero) reserve ratio is not applied/ the total of liabilities included in the reserve base to which a 0 (zero) reserve ratio is not applied to" of the bank is higher than 50 (fifty) percent."

- Overnight deposits - the interest rate of overnight deposits remained unchanged throughout 2020 at a $0.10 \%$ rate

- One-day loans - the interest rate of one-day loans decreased by 100 basis points from $1.90 \%$ to $0.90 \%$ in March and thus remained until the end of 2020.

- Liquidity management and implementation of monetary policy - in terms of this monetary policy tool, routine forecasts of the need for liquidity are made and for different periods

All changes in the traditional tools of the country's monetary policy during 2020 are presented in Table 3, while the required reserves ratios are presented in Table 4.

The central bank changed the Non-traditional tools of the Republic of Albania as follows (Bank of Albania, 2020e):

- Extension of debt payment deadline - the banks and non-bank financial entities were relieved to defer loan installments to their customers for six months due to the difficult financial situation of the pandemic, which only was applied to clients whose financial deterioration was found because of the pandemic.

- Suspension of the banking sector's dividend distribution- the distribution of the banking sector - the distribution of the dividend of the banking sector is suspended during 2020.

- Reduction of infrastructure system electronics costs - the costs of commissions applied by banks for lek credit transfers in non-paper form from their customers were removed, as well as the fees for participants in the AIPS and AECH payment systems operated by the Bank of Albania, starting April 10, 2020. 
Table 3

Interest rates of traditional monetary policy tools in the Republic of Albania in 2020

\begin{tabular}{lccc}
\hline Month & Overnight Deposits & Treasury Bills & Overnight Loans \\
\hline January & $0.10 \%$ & $1.00 \%$ & $1.90 \%$ \\
February & $0.10 \%$ & $1.00 \%$ & $1.90 \%$ \\
March & $0.10 \%$ & $1.00 \%$ & $1.90 \%$ \\
April & $0.10 \%$ & $0.50 \%$ & $0.90 \%$ \\
May & $0.10 \%$ & $0.50 \%$ & $0.90 \%$ \\
Juny & $0.10 \%$ & $0.50 \%$ & $0.90 \%$ \\
July & $0.10 \%$ & $0.50 \%$ & $0.90 \%$ \\
August & $0.10 \%$ & $0.50 \%$ & $0.90 \%$ \\
September & $0.10 \%$ & $0.50 \%$ & $0.90 \%$ \\
October & $0.10 \%$ & $0.50 \%$ & $0.90 \%$ \\
November & $0.10 \%$ & $0.50 \%$ & $0.90 \%$ \\
December & $0.10 \%$ & $0.50 \%$ & $0.90 \%$ \\
\hline Source:Auth' & & & \\
\hline
\end{tabular}

Source: Authors' calculations

Table 4

Banks' reserves requirement ratios in the Republic of Albania in 2020

\begin{tabular}{lc}
\hline Year & 2020 \\
\hline Banks' reserve requirement ratios in domestic currency - maturity term of & $7.50 \%$ \\
liabilities up to 12 months & $5.00 \%$ \\
Banks' reserve requirement ratios in domestic currency - maturity term of & $12.50 \%$ \\
liabilities over 12 months to 2 years & \\
Banks' reserve requirement ratios in foreign currency - when the ratio of & "liabilities in the relevant currency included in the reserve base to which a 0 \\
(zero) reserve ratio is not applied/ the total of liabilities included in the reserve & \\
base to which a 0 (zero) reserve ratio is not applied to" of the bank is up to 50 & $20.00 \%$ \\
(fifty) percent". & \\
Banks' reserve requirement ratios in foreign currency - when the ratio of & \\
"liabilities in the relevant currency included in the reserve base to which a 0 & \\
(zero) reserve ratio is not applied/ the total of liabilities included in the reserve & \\
base to which a 0 (zero) reserve ratio is not applied to" of the bank is higher \\
than 50 (fifty) percent".
\end{tabular}

The space of interbank interest rate volatility was changed toward narrowing by 100 basis points. This is because the interest rate of overnight loans decreased by 100 basis points from $1.90 \%$ to $0.90 \%$ and thus remained until the end of 2020 .

In parallel with the narrowing of the space for volatility, the interbank interest rate itself decreased by 50 basis points $1.00 \%$ to $0.50 \%$ in March and thus remained until the end of 2020. Changes in both the interbank interest rate and the volatility space of the interbank interest rate are shown by a graph in Figure 3. 
Figure 3

Interest Rates of Traditional Monetary Policy Tools (except Required Reserve) in the Republic of Albania in 2020

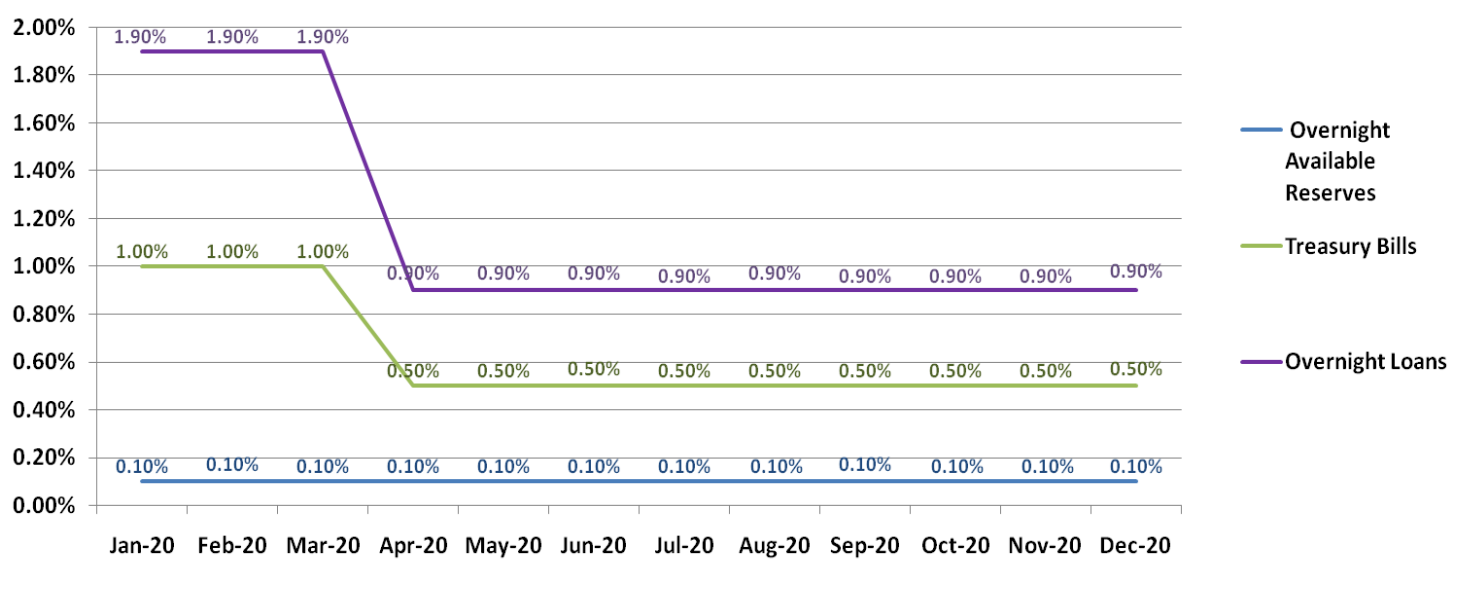

Source: Authors' calculations

The dynamic analysis is presented by a graph in Figure 4 and shows that the interbank interest rate decreased relatively slightly more than the interest rate of overnight loans. In April, the interbank interest rate decreased by $50 \%$, and the overnight loan interest rate decreased by $53 \%$.

Figure 4

Dynamic Analysis of Interest Rates of Traditional Monetary Policy Tools in the Republic of Albania in 2020

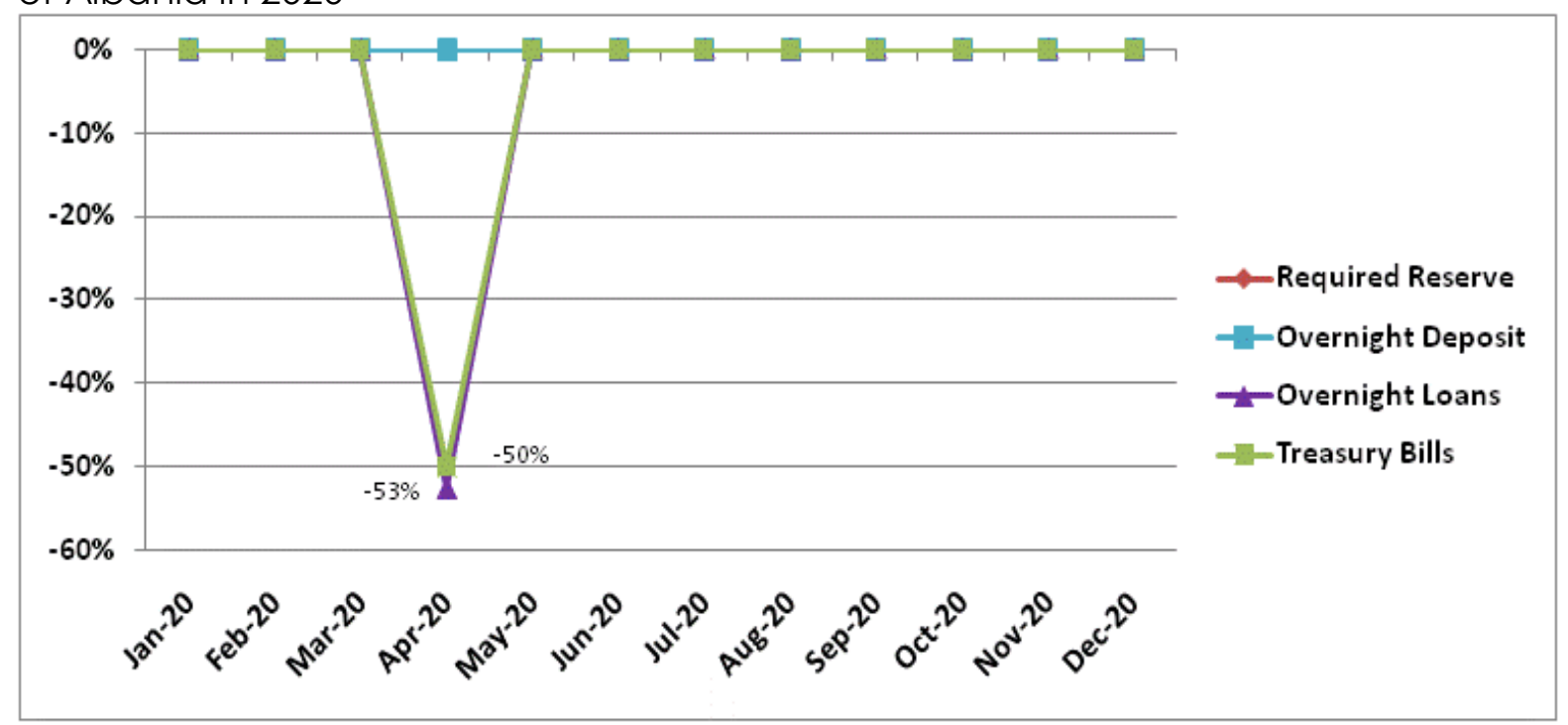

Source: Authors' calculations

Based on the changes made to the traditional and non-traditional tools, the conditions are met to conclude that an expansionary monetary policy was pursued an expansionary monetary policy in the Republic of Albania during the pandemic period for 2020.

\section{Conclusion}


The main conclusion is that both countries pursued expansive monetary policies by central banks to cope with the Covid 19 pandemic. This expansionary policy was realized by easing traditional monetary policy tools, and non-traditional tools were also applied that have contributed to monetary expansion. With the traditional tools, not all of them changed in both countries. For the Republic of North Macedonia, the following was changed: in April, the interbank interest rate was reduced with $13 \%$ (from $2.00 \%$ to $1.75 \%$ ), and the overnight loan interest rate was reduced by $10 \%$ (from $2.50 \%$ to $2.25 \%$ ), while in May there was another reduction of the interbank interest rate with $14 \%$ (from $1.75 \%$ to $1.50 \%$ ) and overnight loan interest rate by $11 \%$ (from $2.25 \%$ to $2.00 \%$ ). For the Republic of Albania, the following was changed: in April, the interbank interest rate was reduced by $50 \%$ (from $1.00 \%$ to $0.50 \%$ ), and the overnight loan interest rate was reduced by $53 \%$ (from $1.90 \%$ to $0.90 \%$ ). The non-traditional tools were used as follows: reactivation of the non-standard reserve demand measure, expansion of the portfolio of eligible securities, tariff reduction, and extension of the deadlines for loans and the bank's liquidity assessment report by the Central Bank of the Republic of North Macedonia, and: debt payment deadlines, suspension of dividend distribution and lower banking sector electronic systems infrastructure costs by the Central Bank of the Republic of Albania. As a result of the changes applied in traditional tools, the volatility space for the interbank interest rate has changed towards narrowing for both countries. In the Republic of North Macedonia, space was narrowed by 50 basis points throughout the year only due to reducing the interest rate on overnight loans from $2.50 \%$ to $2.25 \%$ in March and $2.00 \%$ in April. It thus was remained unchanged until the end of 2020, while in the Republic of Albania, space was narrowed by 100 basis points due to the reduction of only the interest rate on overnight loans from $1.90 \%$ to $0.90 \%$ on March 25 and thus was remained until the end of 2020. The disadvantage of this study is that there isn't an analysis of the economic effects of the measures taken by the monetary policy authorities, given through the change of traditional and non-traditional tools, mainly since it is still too early to make such an analysis.

\section{References}

1. Amadeo, K. (2021), "The balance", available at: https://www.thebalance.com/monetary-policy-tools-how-they-work-3306129 (01 June 2021)

2. Bank of Albania (2020a), "NJOFTIM PËR SHTYP: Fjala e Guvernatorit Sejko në konferencën për shtyp për vendimmarrjen e politikës monetare, 7 tetor 2020" ("PRESS CONFERENCE: Speech of Governor Sejko at the press conference on monetary policy decision-making, October 7, 2020"), available at: https://www.bankofalbania.org/Shtypi/Fjalime_intervista_artikuj/Fjalime/Fjala_e_Guve rnatorit_Sejko_ne_konferencen_per_shtyp_per_vendimmarrjen_e_politikes_monetare_ 7_tetor_2020.html (01 April 2021)

3. Bank of Albania (2020b), "COVID-19", available at: https://www.bankofalbania.org/Press/COVID-19/(01 April 2021)

4. Bank of Albania (2020c), "Bank of Albania", available at: https://en.wikipedia.org/wiki/Bank_of_Albania (01 June 2021)

5. Bank of Albania (2020d), "Rezerva e Detyruar" ("Compulsory Reserve"), available at: https://www.bankofalbania.org/Politika_Monetare/Instrumentet/Rezerva_e_Detyruar/ (01 June 2021)

6. Bank of Albania (2020e), "On the order of the Bank of Albania and the Prime Minister on the extension of the deadline of payment of loans to enterprises and households", available at:

https://www.bankofalbania.org/Press/On_the_order_of_the_Bank_of_Albania_and_th 
e_Prime_Minister_on_the_extension_of_the_deadline_of_payment_of_loans_to_enterp rises_and_households.html (01 June 2021)

7. Bank of Albania (2021), "Brief history of Bank of Albania", available at: https://www.bankofalbania.org/About_the_Bank/Brief_history_of_Bank_of_Albania/ (01 March 2021)

8. Friedman, B. M. (2015), "Monetary Policy since the 2007-2009 Financial Crisis", in International Encyclopedia of the Social \& Behavioral Sciences, pp. 727-734.

9. Kenton, W. (2021), "Investopedia", available at: https://www.investopedia.com/terms/n/nonstandard-monetarypolicy.asp\#: : :text=Traditional\%20monetary\%20policies\%20include\%20the,adjustments \%2C\%20and\%20negative\%20interest\%20rates (01 March 2021)

10. Loayza, N. V., Pennings, S. (2021), "Macroeconomic Policy in the Time of COVID-19", available at: https://www.nbrm.mk/ns-newsarticle-soopstenie-1832020-al.nspx (01 April 2021)

11. NBRM (2020a), "Monthly weighted average interest rate on Central Bank bills auctions", available at: https://www.nbrm.mk/mesecni-ponderirani-kamatni-stapkina-blagajnickite-zapisi-en.nspx (01 June 2021)

12. NBRM (2020b), "Reserve requirement", available at: https://www.nbrm.mk/zadolzhitielna_rezerva-en.nspx (01 April 2021)

13. NBRM (2020c), "Deposit Facility", available at: https://www.nbrm.mk/raspolozhlivi_diepoziti-en.nspx (01 June 2021)

14. NBRM (2020d), "Banka Popullore është duke arritur me sukses qëllimet e saj dhe sistemi bankar është i përgatitur për t'u marrë me krizën e koronës" ("The National Bank is successfully achieving its goals and the banking system is prepared to deal with the corona crisis"), available at: https://www.nbrm.mk/ns-newsarticle-soopstenie-2942020al.nspx (01 April 2021)

15. Smaghi, L. B. (2009), "Conventional and Unconventional Monetary Policy", available at: https://www.bis.org/review/r090429e.pdf (01 June 2021)

16. World Bank (2021), "Western Balkans regular economic report", available at: https://www.worldbank.org/en/region/eca/publication/western-balkans-regulareconomic-report (01 June 2021)

\section{About the authors}

Alba Pollozhani is an MBA student in Finance and Accounting at SEEU University. She graduated with bachelor studies from SEEU University, Faculty of Business and Economics. She is an experienced accountant and also an experienced marketing manager in a manufacturing business. Her research interests are macroeconomic policies, management, and marketing. The author can be contacted at ap24354@seeu.edu.mk

Shenaj Hadzimustafa, Ph.D., is an Associate Professor at the Faculty of Business and Economics, South East European University in Tetovo. She received a Ph.D. in Economics with the dissertation thesis "The Knowledge Economy and sustainable development with special accent on the Republic of Macedonia." She is an experienced professor in macroeconomics, economic growth and development, development management, etc. She has several scientific published works, prosperous academic experience, and different achievements in scientific research and teaching activities (scientific and professional papers, seminars, conferences, educational activities, projects, etc.). The author can be contacted at s.daut@seeu.edu.mk 